\title{
Research on Real Estate Industry Cost Stickiness and Its Influencing Factors
}

\author{
Yuemei Wang \\ Wuhan University of Technology School of Management
}

2273248963@qq.com

Keywords: Real estate industry; Cost stickiness; Influencing factors; Management

\begin{abstract}
The research on cost stickiness behavior is mainly about sales \& administrative cost and manufacturing industry, lacking studies on particular niche business. Therefore, the real estate industry paid highly attention was chosen as the research object and an empirical analysis of cost stickiness behavior and its affecting factors was conducted. By analyzing the accounting data of China listed companies of real estate industry from 2008 to 2015, the empirical results show that:(1) The listed companies of real estate industry did have cost stickiness behavior;(2) Inventory density and human capital density have strengthened the degree of cost stickiness behavior;(3) The cost stickiness of real estate companies in economic prosperity period is higher than that in economic recession period; The cost stickiness of state-owned enterprises is higher than that of non-state-owned enterprises.
\end{abstract}

CLC number F276.6 Document identification code: A

\section{Introduction}

With the development of economic prosperity, real estate companies are facing more complex economic environment and fierce market competition. Cost forecast also put forward higher requirements on the real estate industry profit and loss analysis. The management often uses income minus cost to forecast the profit, therefore the accuracy of the cost estimate decides the reasonableness of the profit and loss analysis to a certain extent. According to the cost behavior theory, the management accounting divides the cost into unit variable cost "a" and fixed cost "b", and establishes the cost estimation model $y=a x+b$. No matter how the traffic " $x$ " changes direction, the cost " $y$ " changes symmetrically with the traffic volume. Although the model is easy to understand, it is too idealistic. Actually, the magnitude of the cost change is related to the direction of the change in traffic, but not to the symmetric change (Noreen, Soderstron, 1997). M. C. Anderson et al. (2003) [1] define the phenomenon of cost increase as the cost of the increase in volume is greater than that of the decrease in cost when the volume decreases. The cost stickiness is the important reason that the cost estimation model does not accord with the practical application. It reduces the accuracy of profit forecast, thus affecting the efficiency of corporate management decision-making.

Although China's scholars for different industries for the company to study the cost stickiness, but ignored the real estate company this important type of company. The cost stickiness of real estate companies will affect the cost control and the factors of cost stickiness can also provide cost control for the company to provide ideas.

\section{Literature Review and Research Hypothesis}

Literature Review. In terms of the existence of cost stickiness, Anderson et al. (2003) demonstrated the existence of cost stickiness by constructing a logarithmic linear regression model of the cost stickiness of the 7629 publicly traded companies in the United States. R. Balakrishnan and T. S. Gruca (2008) [2] found that hospital operating costs were sticky. N. Farzaneh et al. (2013) [3] have also validated the existence of cost stickiness by empirical studies of firms listed on the Tehran Stock Exchange from 2001 to 2010. But N. D. Via and P. Perego (2014) [4] studied corporate data from 1999 to 2008 in Italy and found that cost stickiness was present only in the total 
cost of labor, not all cost. China's research on cost stickiness started late. Z. Sun and H. Liu (2004), Y.S. Kong (2007) [5] through empirical studies to confirm the existence of cost stickiness.

In terms of the factors of cost stickiness, K. Calleja et al. (2006) [6] consider the impact of some common factors on the degree of cost stickiness, such as capital intensity, labor intensity, debt ratio, among which only capital intensity and labor intensity have a positive effect on the degree of stickiness of costs. S.Y. Wan and S.N. Xu (2012) [7] divided the company into state-owned and non-state-owned according to the nature of property rights, and found that the cost of state-owned listed companies is higher than non-state-owned listed companies. W. Liu (2006)'s [8] empirical study found that the decline in sales revenue and macroeconomic growth factors such as the company's cost stickiness industry differences have an impact, in which macroeconomic growth on the real estate industry has increased the cost stickiness, the role of other industries (Excluding the financial industry) have weakened. In addition, some scholars have studied the effect of variables such as accrual earnings management (W. Jiang et al., 2015), managerial overconfidence (S.K. Liang, 2015) [9], and financing constraints (W. Jiang et al., 2015).

In terms of the industry of cost stickiness, Y.S. Kong and other scholars have come to the conclusion that the cost stickiness degree of different listed companies in China is different in 2007. Q. Pang and J.P. Zhang (2015) [10] through empirical verification of the existence of the cost stickiness of manufacturing companies, and the study of asset concentration, inventory density and other factors affect cost stickiness. The study of C.L. Yang et al. (2015) [11] confirms the existence of high-tech firms' cost stickiness. P. Liu and W. He (2015) [12] verified the existence of cost stickiness in the listed companies of transportation industry through the data of the listed companies in 1994-2013. In addition, there are some scholars on the power (H.M. Chen and Z.H. Li, 2015), new energy (J.R. Tang and Y.T. Kong, 2014) [13] and other industries cost stickiness study. By combing the literature, I find that there are few studies on the existence and the influencing factors of cost stickiness for real estate companies. This study will make up for this deficiency.

Research Hypothesis. Based on the agency theory, when the real estate company sales decline, the management does not reduce their salaries, and when the sales performance up, but will require a raise. While management often left idle resources for backup, so the real estate company's cost does not change with the change in sales performance of the relative change occurs. In addition, based on incomplete contract theory, if the real estate company cannot accurately predict the cost of change, then when the decline in sales, you cannot adjust cost in time. As a result, cost stickiness occurs. Thus, Hypothesis 1 of this paper is formed as follows:

Hypothesis 1: The real estate industry has cost stickiness.

Based on the view of efficiency, because the management of real estate companies will think that the decline of sales performance is only temporary, there is no need to adjust the allocation of resources immediately, and the real estate companies usually allocate resources ahead of schedule. Therefore, when the sales performance declines, the previous decisions are difficult to change, companies can control costs less, and change the decision to adjust the cost will be higher, thus increasing the company's cost stickiness. Thus, Hypothesis 2 of this paper is formed as follows:

Hypothesis 2: The cost stickiness of real estate listed companies is positively correlated with inventory intensity.

Based on transaction cost theory, real estate companies management personnel adjustment configuration will occur when the adjustment of costs, in order not to produce the expected cost, may not adjust staffing. At the same time, real estate companies generally pay attention to sales links, will invest a lot of manpower and material resources, when the decline in sales, the corresponding unit of product changes in the cost of a significant change, but the total will not have too big change, Cost stickiness will be increased. Thus, Hypothesis 3 of this paper is formed as follows:

Hypothesis 3: The cost stickiness of real estate listed companies is positively correlated with labor intensity.

Based on manager expectations, managers optimistic about the company's future sales performance, then the current decline in sales will still be put into cost costs, in order to maintain 
the normal level of output, the cost stickiness increased; If managers have pessimistic attitude about the company's future sales performance, they will reduce the cost of inputs, in order to reduce the level of output, so the cost stickiness decreased. Macroeconomic environment is an important factor affecting managers' future expectations. Thus, Hypothesis 4 of this paper is formed as follows:

Hypothesis 4: Compared with the economic downturn, real estate listed companies in the economic boom period showed a higher degree of cost stickiness.

Because of the imperfect market economy in our country, the state-owned company occupies play a very important role in the real estate industry; Our country lacks effective regulations on the cost disclosure of state-owned companies; There is no specific accounting standards, so the cost of state-owned company management efficiency is relatively low. Thus, Hypothesis 5 of this paper is formed as follows:

Hypothesis 5: Compared to non-state-owned real estate listed companies, state-owned real estate listed companies show a higher degree of cost stickiness.

\section{Research And Design}

Sample Selection And Data Sources. The object of this paper is "real estate" company delineated in "Guideline of Industry Classification of Listed Company" which revised by China Securities Regulatory Commission in 2012. Since the implementation of the company in 2007 from the Ministry of Finance in 2006 promulgated the "Accounting Standards for Business Enterprises", so the sample selection of the Shanghai and Shenzhen Stock Exchange real estate listed companies from 2008-2015 data. Sample data from the CSMAR database. I used the following criteria to screen the sample companies: (1) select companies listed before 2007 to ensure the integrity of the sample data; (2) remove the ST company data; (3) remove the obvious error information observations, Such as operating income, the cost of zero or the cost of the negative and so on. After screening, a total of 118 real estate companies listed in the 940 observations in line with the above conditions finally.

Variable Definition. In this paper, logarithmic regression model constructed by Anderson et al. (2003) is used as the basis and four variables of inventory intensity, labor intensity, macroeconomic environment and property rights are taken as the corresponding variables of the real estate company's cost stickiness. The influence of these factors on the degree of cost stickiness was investigated. Table 1 shows the names and descriptions of the variables used in the logistic regression model.

Table 1 Variable description

\begin{tabular}{l|l}
\hline Variable & Definition \\
\hline SGA & sales and general administration cost \\
\hline REV & Operating income this year \\
\hline DI & Inventory intensity, the ratio of inventories to sales for the year \\
\hline EI & $\begin{array}{l}\text { Labor intensity, the ratio of the number of employees at the end } \\
\text { of year to operating income(million rials) of the current year }\end{array}$ \\
\hline GDP & $\begin{array}{l}\text { Dummy variable, the 2008-2015 GDP growth rate of the median } \\
\text { as the standard, greater than the median of the year is divided } \\
\text { into economic boom, take 1, otherwise divided into economic } \\
\text { downturn, take } 0\end{array}$ \\
\hline STATE & $\begin{array}{l}\text { Dummy variable, taken } 1 \text { by the state-owned company, 0 is taken } \\
\text { by the non-state-owned company }\end{array}$ \\
\hline
\end{tabular}

Empirical Models. This paper first follows the logarithmic regression model design model (1) of Anderson et al. (2003). $S G A_{i, t}$ represents the sum of SGA of listed companies this year. $R E V_{i, t}$ shows operating income of listed companies this year. $D_{i, t}$ is the dummy variable, when the 
operating income of period $\mathrm{t}$ minus the operating income of period $\mathrm{t}-1$ is less than zero, $D_{i, t}$ take 1 , otherwise take 0 . The coefficient $\alpha_{1}$ is used to indicate that when the revenue is increased by $1 \%$, the change of cost is $\alpha_{1} \% . \quad \alpha_{1}+\alpha_{2}$ means that the change of cost is $\alpha_{1}+\alpha_{2} \%$ when the revenue is reduced by $1 \%$. If the Listed companies have cost stickiness, $\alpha 2$ must be negative, while the smaller the value of $\alpha 2$, the higher degree of cost stickiness.

$$
\ln \left(\frac{S G A_{i, t}}{S G A_{i, t-1}}\right)=\alpha_{0}+\alpha_{1} * \ln \left(\frac{R E V_{i, t}}{R E V_{i, t-1}}\right)+\alpha_{2} * D_{i, t} \ln \left(\frac{R E V_{i, t}}{R E V_{i, t-1}}\right)+\varepsilon_{i, t}
$$

In order to test hypothesis 2 and hypothesis 3, on the basis of the logarithm model, we add the measurement indexes of stock intensity $\left(D I_{i, t}\right)$, labor intensity $E I_{i, t}$, as shown in model (2) and (3). If $\beta_{3}$ and $\beta_{4}$ are negative, the regression results support hypothesis 2 and hypothesis 3 respectively.

$$
\begin{aligned}
\ln \left(\frac{S G A_{i, t}}{S G A_{i, t-1}}\right) & =\beta_{0}+\beta_{1} * \ln \left(\frac{R E V_{i, t}}{R E V_{i, t-1}}\right)+\beta_{2} * D_{i, t} \ln \left(\frac{R E V_{i, t}}{R E V_{i, t-1}}\right)+\beta_{3} * D I_{i, t} * D_{i, t} \ln \left(\frac{R E V_{i, t}}{R E V_{i, t-1}}\right) \\
& +\varepsilon_{i, t} \\
\ln \left(\frac{S G A_{i, t}}{S G A_{i, t-1}}\right) & =\beta_{0}+\beta_{1} * \ln \left(\frac{R E V_{i, t}}{R E V_{i, t-1}}\right)+\beta_{2} * D_{i, t} \ln \left(\frac{R E V_{i, t}}{R E V_{i, t-1}}\right)+\beta_{4} * E I_{i, t} * D_{i, t} \ln \left(\frac{R E V_{i, t}}{R E V_{i, t-1}}\right) \\
& +\varepsilon_{i, t}
\end{aligned}
$$

In order to test the impact of hypothesis 4 and hypothesis 5, namely the macroeconomic environment and the nature of property rights on cost stickiness, the model (4) is used for grouping regression.

$$
\ln \left(\frac{S G A_{i, t}}{S G A_{i, t-1}}\right)=\gamma_{0}+\gamma_{1} * \ln \left(\frac{R E V_{i, t}}{R E V_{i, t-1}}\right)+\gamma_{2} * D_{i, t} \ln \left(\frac{R E V_{i, t}}{R E V_{i, t-1}}\right)+\varepsilon_{i, t}
$$

\section{The Empirical Results And Analysis}

Descriptive Statistical Analysis. From Table 2, it can be found that the average rate of change of SGA of real estate listed companies is $13.42 \%$ and the average rate of change of business income is $11.56 \%$. The rising rate of SGA is higher than that of operating income, which is consistent with the findings of Yusheng Kong (2007). This shows there is a low operating efficiency of the phenomenon of cost management in China's real estate industry as other industries. The SGA accounts for $30.74 \%$ of operating income, indicating the SGA accounted for a higher proportion of operating income and the level of control over the SGA is to be improved. The average inventory density is about 5.84, and the average labor intensity is 1.38 . In the macroeconomic environment, due to the impact of the financial crisis, the slowdown in China's GDP growth in recent years, coupled with China is no longer too much to pursue high GDP growth rate, the requirements for sound and rapid development, so 2008 to 2015 GDP with an average growth rate of $8.56 \%$ and a GDP growth rate of $6.9 \%$ in 2015 . In the nature of property rights, $53.19 \%$ of the real estate company eventually controlled man-made, more than half of the total. Table 3 is the correlation coefficient between the variables table, we can find that there is no multiple collinear variables between the problem. 
Table 2 Sample descriptive statistics

\begin{tabular}{l|l|l|l|l|l|l}
\hline Variable & Number & Mean & Std-dev & Median & Min & Max \\
\hline $\ln \left(\frac{S G A_{i, t}}{S G A_{i, t-1}}\right)$ & 940 & 0.134 & 0.464 & 0.103 & -1.863 & 4.747 \\
\hline $\ln \left(\frac{R E V_{i, t}}{R E V_{i, t-1}}\right)$ & 940 & 0.116 & 0.910 & 0.099 & -4.157 & 9.608 \\
\hline SGA(Million Rials) & 940 & 333.181 & 778.218 & 132.995 & 2.734 & 10699.43 \\
\hline REV(Million Rials) & 940 & 4601.072 & 14542.4 & 1506.057 & 0.326 & 207000 \\
\hline$S G A_{i, t}$ & 940 & 0.307 & 1.723 & 0.092 & 0.021 & 44.555 \\
\hline$R E V_{i, t}$ & & & & & & \\
\hline IN(Million Rials) & 940 & 11804.43 & 33177.64 & 3351.204 & 0 & 397000 \\
\hline EM & 940 & 2183.991 & 5055.635 & 735 & 0 & 49040 \\
\hline DI & 940 & 5.840 & 50.361 & 2.416 & 0 & 1436.07 \\
\hline EI & 940 & 1.381 & 4.051 & 0.484 & 0 & 72.633 \\
\hline GDP & 940 & 0.086 & 0.012 & 0.077 & 0.069 & 0.106 \\
\hline STATE & 940 & 0.532 & 0.499 & 1 & 0 & 1 \\
\hline
\end{tabular}

Table 3 Sample descriptive statistics

\begin{tabular}{l|l|l|l|l}
\hline & $\ln \left(\frac{S G A_{i, t}}{S G A_{i, t-1}}\right)$ & $\ln \left(\frac{R E V_{i, t}}{R E V_{i, t-1}}\right)$ & $\mathrm{DI}$ & $\mathrm{EI}$ \\
\hline $\ln \left(\frac{S G A_{i, t}}{S G A_{i, t-1}}\right)$ & 1.0000 & & & \\
\hline $\ln \left(\frac{R E V_{i, t}}{R E V_{i, t-1}}\right)$ & $0.6106^{* * *}$ & 1.0000 & & \\
\hline DI & -0.0154 & $0.1923^{* * * *}$ & 1.0000 & \\
\hline EI & $0.0579^{*}$ & $0.3156^{* * *}$ & $0.5968^{* * *}$ & 1.0000 \\
\hline
\end{tabular}

Note: $* * *, * *, *$ indicate significant at the 1,5 , and $10 \%$ confidence levels respectively.

Cost Stickiness. In this paper, we use Eq. 1 to verify hypothesis 1 . As shown in Table 4, both $\alpha_{1}$ and $\alpha_{2}$ are significant at the $1 \%$ confidence level, and $\alpha_{2}$ is negative. The regression results of Eq. 1 in Table 4 are analyzed. When the operating income is increased by $1 \%$, the company's SGA are increased by $0.387 \%$. When the sales revenue is reduced by $1 \%$, the company's SGA is reduced by $0.084 \%$. We can see that the decline in operating income when the company's decline in SGA lower than the increase in operating income when the company's SGA rise. The above analysis confirms the hypothesis 1 that China's real estate listed companies do exist cost stickiness.

Cost Stickiness and Firm Characteristics. In this paper, we use the Eq. 2 to test the impact of inventory intensity on the degree of cost stickiness of real estate listed companies. As shown in the regression results of Eq.2 in Table 4, the inventory density is significantly negative at the $1 \%$ confidence level, indicating that the higher the inventory intensity is, the higher the cost stickiness is. Hypothesis 2 holds.

In this paper, we use the Eq.3 to test the impact of labor intensity on the cost stickiness of real estate listed companies. As shown in the regression result of Eq.3 in Table 4, the coefficient of labor 
intensity in the model is significantly negative at the $10 \%$ confidence level, indicating that the greater the labor intensity, the higher the cost stickiness. Hypothesis 3 holds.

Table 4 Cost Stickiness: estimations with Eq.1,2,3

\begin{tabular}{l|l|l|l}
\hline Variable & Eq.1 & Eq.2 & Eq.3 \\
\hline cons & $\begin{array}{l}0.0309^{* *} \\
(2.04)\end{array}$ & $\begin{array}{l}0.0353^{* *} \\
(2.34)\end{array}$ & $\begin{array}{l}0.0346^{* *} \\
(2.27)\end{array}$ \\
\hline $\ln \left(\frac{R E V_{i, t}}{R E V_{i, t-1}}\right)$ & $\begin{array}{l}0.387^{* * *} \\
(20.96)\end{array}$ & $\begin{array}{l}0.386^{* * *} \\
(21.01)\end{array}$ & $\begin{array}{l}0.386^{* * *} \\
(20.93)\end{array}$ \\
\hline$D_{i, t} \ln \left(\frac{R E V_{i, t}}{R E V_{i, t-1}}\right)$ & $-0.303^{* * *}$ & $\begin{array}{l}-0.265^{* * *} \\
(-6.34)\end{array}$ & $\begin{array}{l}-0.267^{* * *} \\
(-5.93)\end{array}$ \\
\hline$D I_{i, t} * D_{i, t} \ln \left(\frac{R E V_{i, t}}{R E V_{i, t-1}}\right)$ & $(-7.47)$ & $-0.000714^{* * *}$ & \\
\hline & & $(-3.52)$ & \\
\hline$E I_{i, t} * D_{i, t} \ln \left(\frac{R E V_{i, t}}{R E V_{i, t-1}}\right)$ & & & $-0.00380^{*}$ \\
\hline$N$ & & 940 & $(-1.81)$ \\
\hline adj. $R^{2}$ & 940 & 0.538 & 0.566 \\
\hline
\end{tabular}

Note: $* * *, * *, *$ indicate significant at the 1,5 , and $10 \%$ confidence levels respectively.

Cost Sticky Group Regression. In order to verify hypothesis 4, this paper divides the sample into two sub-samples according to the median of the macroeconomic environment (GDP) variable. The regression results are shown in Table 5. $\gamma_{1}$ and $\gamma_{2}$ of the economic recession group are significant at the $1 \%$ confidence level, and $\gamma_{2}=-0.251<0$. When operating income rose $1 \%$, the SGA rose $0.287 \%$; when operating income decreased by $1 \%$, the sales charge reduced $0.036 \%$. $\gamma_{1}^{\prime}$ and $\gamma_{2}^{\prime}$ in the economic boom group are significant at the $1 \%$ confidence level, and $\gamma_{2}^{\prime}=-0.333<0$. When operating income rose $1 \%$, the pipe costs rose $0.440 \%$; when operating income decreased by $1 \%$, the SGA to reduce $0.106 \%$. As for $\gamma_{2}>\gamma_{2}^{\prime}$, hypothesis 4 holds. The cost stickiness of real estate listed companies in the economic boom is higher than which in the economic downturn.

In order to verify hypothesis 5, this paper divides the sample into two subsamples of state-owned company and non-state-owned company according to the property of STATE, and returns the results to sub-sample separately. $\gamma_{1}$ and $\gamma_{2}$ of the state-owned company group are significant at the $1 \%$ confidence level, and $\gamma_{2}=-0.327<0$. When operating income rose $1 \%$, the SGA rose $0.280 \%$; when operating income decreased by $1 \%$, the SGA reduced $-0.47 \%$. The $\gamma_{1}^{\prime}$ and $\gamma_{2}^{\prime}$ of the non-state-owned group were significant at the $1 \%$ confidence level, and $\gamma_{2}^{\prime}=-0.266<0$. When the operating income rose $1 \%$, the SGA rose $0.381 \%$; when operating income decreased by $1 \%$, the SGA reduce $0.115 \%$. As for $\gamma_{2}<\gamma_{2}^{\prime}$, hypothesis 5 holds. The cost stickiness of state-owned real estate listed companies is higher than non-state-owned listed companies. 
Table 5 Cost sticky group regression

\begin{tabular}{l|l|l|l|l}
\hline Variable & $\begin{array}{l}\text { economic } \\
\text { recession period }\end{array}$ & $\begin{array}{l}\text { economic } \\
\text { prosperity period }\end{array}$ & $\begin{array}{l}\text { state-owned } \\
\text { enterprises }\end{array}$ & $\begin{array}{l}\text { non-state-owned } \\
\text { enterprises }\end{array}$ \\
\hline cons & $\begin{array}{l}0.287^{* * *} \\
(10.25)\end{array}$ & $\begin{array}{l}0.440^{* * *} \\
(14.58)\end{array}$ & $\begin{array}{l}0.280^{* * * *} \\
(7.13)\end{array}$ & $\begin{array}{l}0.381^{* * *} \\
(15.32)\end{array}$ \\
\hline $\ln \left(\frac{R E V_{i, t}}{R E V_{i, t-1}}\right)$ & $\begin{array}{l}-0.251^{* * *} \\
(-3.92)\end{array}$ & $\begin{array}{l}-0.334^{* * *} \\
(-4.84)\end{array}$ & $\begin{array}{l}-0.327^{* * *} \\
(-4.28)\end{array}$ & $\begin{array}{l}-0.266^{* * *} \\
(-4.93)\end{array}$ \\
\hline \multirow{2}{*}{$\ln \left(\frac{R E V_{i, t}}{R E V_{i, t-1}}\right)$} & $\begin{array}{l}0.0407^{* *} \\
(2.26)\end{array}$ & $\begin{array}{l}0.0281 \\
(1.03)\end{array}$ & $\begin{array}{l}0.0215 \\
(1.15)\end{array}$ & $\begin{array}{l}0.0601^{* *} \\
(2.33)\end{array}$ \\
\hline$N$ & 471 & 469 & 500 & 440 \\
\hline adj. $R^{2}$ & 0.364 & 0.594 & 0.166 & 0.843 \\
\hline
\end{tabular}

Note: $* * *, * *, *$ indicate significant at the 1,5 , and $10 \%$ confidence levels respectively.

\section{Conclusions}

In this paper, through empirical research on the real estate listed companies in Shanghai and Shenzhen Stock Exchange from 2008 to 2015, it is found that there are cost stickiness in the real estate listed companies. At the same time, it is found that the cost stickiness of the real estate listed companies is closely related to inventory intensity, labor intensity, macroeconomic environment, and property rights. Among them, the inventory intensity, labor intensity and the cost stickiness is positively correlated; Real estate listed companies in the economic boom of the cost of sticky degree is higher than the economic downturn period; The cost stickiness of state-owned real estate listed companies degree is higher than non-state-owned real estate listed companies.

\section{Recommendations}

In order to control the cost stickiness of the real estate company, this paper proposes the following recommendations:

(1) Strengthen cost management, improve cost management efficiency. Real estate companies will expand product sales, and achieve product value as the company's operating center. Management often pay more attention to the cost of production control, and is easy to ignore the excessive cost of pipe investment, such as the promotion of ineffective and unreasonable reimbursement. The Company strengthened the review on the use of the selling expenses, and kept the selling expenses within a reasonable range, which reduced the stickiness of the sales expenses. Compared to non-state-owned companies with relatively transparent cost management, state-owned companies should increase the efficiency of cost management.

(2) To strengthen the inventory, labor-intensive control. On the one hand, real estate companies should be based on the forecast of market demand for the preparation of budget, in the implementation of the budget according to the actual situation, adjust the company's production and inventory inventory are maintained at a reasonable range, make full use of company resources; On the other hand, facing changing market environment, real estate companies should introduce talent reasonably and control labor intensity.

(3) To strengthen the macroeconomic response. In times of economic upturn, to prevent over-investment in real estate companies caused by too much pressure the on cost of recovery. In times of economic downturn, to avoid the company's management is too optimistic expectations, and adjust the cost of resource allocation, to reduce cost stickiness. 


\section{References}

[1] M. C. Anderson, R. D. Banker and S. N. Janakiraman: Are Selling, General, and Administrative Costs "Sticky"? Journal of Accounting Research, Vol. 41 (2003) No.1, p.47-63.

[2] R. Balakrishnan and T. S. Gruca: Cost Stickiness and Core Competency: A Note. Contemporary Accounting Research, Vol. 25 (2008) No.4, p.993-1006.

[3] N. Farzaneh, S. M. Javad, S. Mahdi and B. S. Ali Haddad: A Study Of The Stickiness Of Cost Of Goods Sold And Operating Costs To Changes In Sales Level In Iran. Studies in Business \& Economics, Vol. 8 (2013) No.2, p.79-89.

[4] N. D. Via and P. Perego: Sticky cost behaviour: evidence from small and medium sized companies. Accounting \& Finance, Vol. 54 (2014) No.3, p.753-778.

[5] Y.S Kong: Naiping Zhu, Qinggen Kong. The study of cost stickiness: empirical evidence from Chinese listed companies. Accounting Research, (2007) No.11, p.58-65+96 (In Chinese).

[6] K. Calleja, M. Steliaros and D. C. Thomas: A note on cost stickiness: Some international comparisons. Management Accounting Research, Vol. 17 (2006) No.2, p.127-140.

[7] S.Y. Wan and S.N. Xu: Chinese listed companies cost sticky empirical evidence - based on the nature of listed companies, the nature of the different control point of view. Audit and Economic Research, (2012) No.4, p.79-86 (In Chinese).

[8] W. Liu: Business costs" sticky "behavior: an empirical study based on industry differences. China Industrial Economy, (2006) No.12, p.105-112 (In Chinese).

[9] S.K. Liang: Managers overconfidence, debt constraints and cost stickiness. Nankai Management Review, (2015) No.3, p.122-131 (In Chinese).

[10] Q. Pang and J.P. Zhang: China's manufacturing companies listed on the cost of sticky behavior of the empirical test. Accounting Monthly, (2015) No.21, p.19-23 (In Chinese).

[11]C.L. Yang, Q. Yang and X. Yu: High-tech enterprise cost stickiness and its objective factors. Modern Management Science, (2015) No.9, p.64-66 (In Chinese).

[12]P. Liu and W. He: Transportation companies listed on the transport costs of sticky. Railway Transport and Economy, (2015) No.8, p.6-10 (In Chinese).

[13] J.R. Tang and Y.T. Kong: New energy industry cost stickiness behavior and its driving factors. Statistics and Information Forum, (2014) No.2, p.70-74 (In Chinese). 